\title{
Mobile Phone Data-based Sociological and Urban Analyses: The Case Study of Brno, Czech Republic
}

\section{Sociologická a urbanistická analýza města vycházející z dat mobilních operátorů v prípadové studii města Brna}

\author{
Eva Horáková \\ Ústav prostorové tvorby, Fakulta architektury, Vysoké učení technické v Brně \\ školitel: doc. Ing. arch. Jiř́i Palacký, Ph.D.
}

\begin{abstract}
Daily movement patterns of inhabitants derived from mobile phone data are one of very valuable data sources for today's sociological and urban analyses of modern cities. These data sets are open but - while being of a limited quality - available on a mobile provider's website. This data enables a number of users in selected areas to be observed through two-hour time slots. It also provides anonymous information about the age and gender of the users. The aim of this paper is to introduce mobile phone data visualisations through a case study of the city of Brno, Czech Republic.
\end{abstract}

KEYWORDS: open data; urban planning; mobile phone data; regional usability; population density; population; Brno

\begin{abstract}
ABSTRAKT: Informace o pohybu uživatelů mobilních sítí patří v dnešní době k ceněným zdrojům dat pro sociologické a urbanistické analýzy denních vzorců chování obyvatel měst. Tato data jsou otevřená, ale v omezené kvalitě publikovaná na webu. Umožňují sledovat množství uživatelů v rámci základních sídelních jednotek ve vybraných průřezových hodinách během celého dne. Data také poskytují anonymizované informace zvlášt o pohlaví a věku uživatelů. Cílem př́íspěvku je představit informace z mobilních dat na př́padové studii vybraných územních celků města Brna.
\end{abstract}

KLÍČOVÁ SLOVA: otevřená data; územní plánování; data mobilních operátorů; využitelnost území; hustota zalidnění; obyvatelstvo; Brno 


\section{Úvod}

Centra měst se potýkají s nejrůznějšími problémy, jedním z nich je i využitelnost lokalit, kterou asi nejlépe charakterizuje počet lidí v území. „Podstatou dobrých území měst a dobrých stavebních projektů dnes stejně jako v minulosti je to, aby se tam mohli lidé snadno a spolehlivě pohybovat, zdržovat se ve městech a stavebních celcích, těšit se $z$ veřejných prostor, budov a městského života, neformálně nebo organizovanějším zpưsobem se setkávat s jinými lidmi." (Gehl, 2000) S využitelností prostředí souvisí i jeho atraktivita. Jednou z možností, jak sledovat počet lidí v území, jsou informace o počtu uživatelů mobilní sítě, které svou charakteristikou spadají pod otevřená data, bezplatně a volně dostupná na internetu ve strukturované a strojově čitelné podobě. (Sashinskaya, 2015)

Tyto informace je možno z hlediska územního plánování rozdělit na data, která jsou publikována městem pro informování jeho obyvatel, a na data tvořená obyvateli, publikovaná třetí stranou, která jsou naopak důležitá pro informovanost města o jeho fungování. Do této druhé skupiny patří i data o uživatelích poskytovaná mobilními operátory, která pro své analýzy využívá např́íklad i pražský Institut plánování a rozvoje (IPR). Fabien Girardin ve své práci dále otevřená data rozděluje dle jejich původu na data pasivní a aktivní. Pasivní data vznikají při interakci infrastruktury jako vedlejší produkt, zatímco obsah aktivních dat je přimo vytvářen uživateli, např́iklad přispěvateli na sociálních sitích. (Girardin, 2014). V rámci tohoto rozdělení spadají mobilní data mezi data pasivní, nebot informace o uživatelích mobilní sítě vznikají při jejich připojení k vysílači a pohyb uživatelů je monitorován jako jejich pohyb mezi jednotlivými vysílači v terénu.

\section{Hypotéza}

Jak zmiňuje ve své práci i Hurník, pro města je naprosto klíčová atraktivita místa. „Město je atraktivita. Lidé každodenně svou přitomností hlasují o atraktivitě mista. Atraktivita je život mista, nebo funkce kupní síly. Neumíme vytvořit atraktivní místa kdekoli, ale navazováním, posilováním atraktivity tam, kde už existuje."(Hurník, 2012) Jednou z hypotéz je, že počet uživatelů mobilní sítě je indikátorem reálného počtu registrovaných i neregistrovaných obyvatel města. Vzorek uživatelů také pomáhá zpřesnit klasifikaci území vzhledem k časoprostorovému chování uživatelů. Dle Institutu plánování a rozvoje $v$ Praze (IPR) jsou mobilní data klíčvým ukazatelem využitelnosti a hustoty osídlení území, $k d y$ v nočních hodinách je největší hustota osídlení v rezidenčních oblastech a pres den se tyto oblasti vylidñují na zhruba poloviční stavy. V průbèhu dne se nejvíce lidí nachází v centru města, v místech velkých kancelářských souborů, $v$ areálech vysokých škol a nemocnic. IPR získal data rozdělená na rezidenty, pracující 
a návštěvníky a sledovaná území dèlí dle vzorcủ chování uživatelů na rezidenční, pracovní území, obslužné území, historické jádro a smíšené území. (Soukup, 2017)

Data, která jsou volně dostupná na serveru poskytovatele mobilních dat O2 Česká republika $(\mathrm{O} 2,2018)$, nejsou rozdělená do kategorií rezident, pracující a návštěvník. Nicméně i tak se dá předpokládat, že průměr počtu uživatelů v nočních hodinách by se měl blížit reálnému počtu lidí v lokalitách, a naopak denní průměr odhalí, které lokality trpí odlivem nebo naopak př́livem uživatelů, a tak pravděpodobně odhalí území s lepší vybaveností a lepšími pracovními podmínkami.

\section{Metodika práce s daty}

Data mobilního operátora $\mathrm{O} 2$ jsou momentálně volně poskytována v rámci rozhraní API na webu $(\mathrm{O} 2,2018)$, odkud je vždy ve středu možné stahovat omezená data pouze z pondělí stejného týdne. Ke stažení dat je potřeba programátorského minima a data je možné ukládat do databáze využívající SQL (SQL je standardizovaný strukturovaný jazyk používaný pro relační databáze, v nichž mají data uloženy vzájemné vztahy), která umožňuje úpravu dat a export do jiných formátů.

Data jsou přiřazena k základním sídelním jednotkám a je možné stahovat sociodemografická data nebo data o mobilitě. Pro účely vizualizací byla stažena sociodemografická data, která umožňují stažení většího objemu dat. Informace je operátorem rozdělena na data o pohybu jednotkou v danou hodinu anebo návštěvě dané jednotky $\mathrm{v}$ čase delším než 30 minut. Data se dále dělí a umožňují stahovat počet mužů a žen v území za stanovené hodiny nebo počet uživatelů ve věkových kategoriích 8-18, 19-25, 26-35, 36-55 a 56+ za stanovené hodiny. Obsahuje-li v dané jednotce v danou hodinu sledovaný segment uživatelů menší než 100 lidí, je hodnota kvůli anonymizaci vyhodnocena jako 0 . U celkového počtu uživatelů daného součtem mužů a žen ve sledované jednotce tedy hodnota 0 odpovídá počtu menšímu než 200 uživatelů za danou hodinu. Jelikož se jedná o informace uživatelů mobilních telefonů, nejsou zde podchycena data uživatelů ve věku do osmi let. Otázkou je, jak byla u operátora nastavená věková hranice, $\mathrm{v}$ dnešní době se určitě najdou i uživatelé mobilního telefonu mladší osmi let, například šestiletí nastupující do škol.

Sledovaná data pocházejí z průměrů dat stažených v květnu (14. 5. 2018, 28. 5. 2018) a jedná se o informace o uživatelích, kteří v dané jednotce strávili více než 30 minut jsou tak filtrováni obyvatelé, kteř́ jednotkou jen projdou.

Přidáním sloupců se vytvořily hodnoty denního průměru 6-18 hodin a nočního průměru 22-6 hodin, které se pro získání hustoty vydělily výměrou místa. 
Po úpravách dat v programu MS Excel byla data ve formátu CSV načtena do softwaru QGIS, kde byla propojena se souborem shapefile (shapefile je datový formát pro ukládání vektorových prostorových dat pro geografické informační systémy) základních sídelních jednotek pomocí kódu ID jednotek, a data byla podle počtu uživatelů $\mathrm{v}$ jednotlivých hodinách klasifikována do 5 tř́́d, kdy 6 . trrídu tvoří data s hodnotou 0 , tj. s celkovým počtem uživatelů nižším než 200.

\section{Výsledky}

Pro př́padovou studii bylo zvoleno město Brno, které momentálně datům začíná věnovat značnou pozornost a během letošního roku spustilo server data.brno.cz. Bylo vybráno několik lokalit, které jsou charakteristické různými urbanistickými uspořádáními města a poskytují tak přehled o denních vzorcích chování uživatelů napříč různými typy městské zástavby.

Následující mapy ukazují, jak vypadá časoprostorové rozvrstvení počtu uživatelů mobilní sítě ve městě Brně v rámci denního dvouhodinového průřezu:

Výše uvedené obrázky ukazují, že okrajové rezidenční lokality se během dne vylidňují na úkor centra a po 18. hodině v nich počet uživatelů opět roste.

V rámci hustoty obyvatel jsou denní i noční průměry přepočítány na výměru jednotky a ukazují tak průměr hustoty uživatelů v území:

Při vydělení denního průměru nočním průměrem jsou lokality s úbytkem hustoty uživatelů přes den vybarveny modře a lokality s př́růstkem hustoty uživatelů přes den vybarvují do teplých barev:

Ze sledovaných lokalit v Brně vyplývají podobné výsledky, jakých se dobral IPR v Praze (Soukup, 2017), kdy v okrajových a převážně rezidenčních oblastech dochází $\mathrm{k}$ poklesu uživatelů během dne a v rámci centra a průmyslovějšího jihu města dochází $\mathrm{k}$ nárůstu. Mezi brněnské lokality s nejvyšším nárůstem patří historické jádro, lokality od jádra na sever kolem ulice Veveří, kde se nachází fakulty různých brněnských univerzit, a lokality za nádražními prostorami, např. Holandská, a dále oblast kampusu v Bohunicích s fakultní nemocnicí.

\section{Diskuze}

Porovnání počtu nočních uživatelů s reálným počtem obyvatel jednotlivých základních sídelních jednotkách je nerelevantní, protože v tomto směru chybí data vzhledem k roku 2011, kdy proběhlo poslední sčítání obyvatel. Tato čísla bude možné porovnat 
až při př́štím sčítání, do kterého se ale určitě upraví přesnost sledování uživatelů mobilní sítě. V rámci sledování denního vzorce chování obyvatel je však metoda použití dat mobilních operátorů celkem vhodná, protože se jí dají uživatelé sledovat téměř v reálném čase, alespoň pro potřeby sociologických urbanistických analýz. Metoda má samozřejmě své meze, spočívající at už v nastavení věkových kategorií a hranice sledování počtu uživatelů od 100 výše, nebo jen v tom, že bez telefonu připojeného do sítě prostě nefunguje. Při porovnání jednotlivých vybraných lokalit je metoda zajímavá právě hustotou zalidnění, kterou dokáže porovnat v rámci dne i noci, pro přesnější určení toho, odkud kam uživatelé migrují, jsou ale volně dostupná data nedostačující.

\section{Závěr}

Závěrem lze říct, že data operátorů zatím nedokážou spolehlivě určit přesný počet obyvatel, protože je v současné době ani není s čím porovnat. Jak popisuje ve svém článku Soukup, tato data se stále potýkají s problémy přesnosti získávaných čísel o obyvatelích, data publikuje jeden operátor, a tak jsou publikovaná data agregována na celkový počet obyvatel, čímž je reprezentativnost vzorku diskutabilní. Dále je přesnost určenépolohy jedince asi 100 m, což může být problémem na hranicích jednotlivých základních sídelních jednotek. Současně v Praze došlo v několika př́padech $i k$ různým rozporům. $Z$ důvodu těchto rozdílností je stále třeba brát data $z$ mobilu jako doplňkový zdroj informací, u kterého je nutná pečlivá kalibrace a obezřetnost při použití. (Soukup, 2017) Nicméně jsou schopna prezentovat základní představu o fungování města

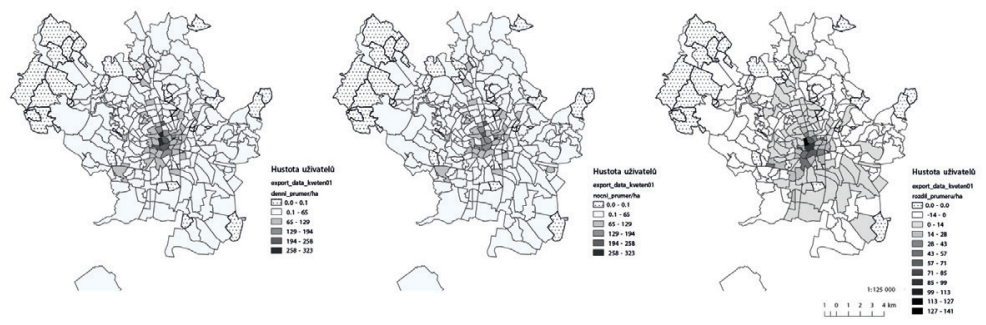

a v rámci územního plánování mohou mít vliv na komerční i rezidenční projekty a jejich lokalizaci, ale hlavně např́ílad na uspořádání městské hromadné dopravy. Do budoucna bych ráda touto metodou porovnala fungování i v dalších městech, např́klad Ostravě a Zlíně, k prokázání nebo vyvrácení podobných výsledků a také více porovnala počty uživatelů mobilní sítě s reálnými počty z celorepublikových sčítání.

Obr. 1. Hustota uživatelů mobilní sítě - denní průměr, noční průměr, srovnání poklesu a nárůstu obou průměrů (zdroj: archiv autora) 


\section{Poděkování}

Tento článek vznikl za podpory projektu GA ČR 17-26104S Vliv charakteru a umístění urbanistické struktury na udržitelný rozvoj území.

\section{Použitá literatura}

GEHL, Jan, 2000. Život mezi budovami: užívání veřejných prostranství. Boskovice: Albert. ISBN 80-858-3479-0.

SASHINSKAYA, Maria, 2015. All you want to know about open data. Brussels: [Createspace Independent Publishing Platform]. ISBN 978-1542893961.

HURNÍK, Petr, 2012. Město. In: KOPEC, Jakub a Szymon ROZWAŁKA, ed. Kompaktní město. Brno: 4AM, 40-69,78-85. ISBN 978-80-905149-0-4.

GIRARDIN, Fabien, 2014. Catching the World's Eyes. In: OFFENHUBER, Dietmar a Carlo RATTI, ed. Decoding the city. Německo: Birkhäuser, s. 18-27. ISBN 9783-03821-597-4.

SOUKUP, Matěj, 2017. Co nám prozradí data z mobilů?. ArcRevue: Časopis pro uživatele softwaru Esri a ENVI. Praha: ARCDATA PRAHA, s.r.o., 25(2), 10-13. ISSN 211-2135.

O2 Liberty API, O2 [online]. [cit. 2018-08-09]. Dostupné z: https://www.o2.cz/podnikatel/liberty-api/ 